\title{
Deinococcus wulumuqiensis sp. nov., and Deinococcus xibeiensis sp. nov., isolated from radiation-polluted soil
}

\author{
Wei Wang, ${ }^{1,2}$ Jun Mao, ${ }^{2}$ Zhidong Zhang, ${ }^{2}$ Oiyong Tang, ${ }^{2}$ Yuqing Xie, $^{2}$ \\ Jing Zhu, ${ }^{2}$ Lixin Zhang, ${ }^{3}$ Zhiheng Liu, ${ }^{3}$ Yuhu Shi ${ }^{1,2}$ \\ and Michael Goodfellow ${ }^{4}$ \\ ${ }^{1}$ Nanjing University of Technology, No. 5 Xinmofan Road, Nanjin 210009, PR China \\ ${ }^{2}$ Institute of Microbiology, Xinjiang Academy of Agricultural Sciences, Urumqi 830091, Xinjiang \\ Uigur Autonomous Region, PR China \\ ${ }^{3}$ Drug Discovery Centre for TB, Institute of Microbiology, Chinese Academy of Sciences, Beijing \\ 100080, PR China \\ ${ }^{4}$ School of Biology, University of Newcastle, Newcastle upon Tyne, NE1 7RU, UK
}

Correspondence

Yuhu Shi

xjsyh2003@yahoo.com.cn

Zhiheng Liu

zhliu@im.ac.cn
The genus Deinococcus was proposed by Brooks \& Murray (1981) to accommodate a group of bacteria of which the most prominent characteristic is extreme resistance to UV light, gamma radiation and desiccation (Mattimore \& Battista, 1996; Callegan et al., 2008; de Groot et al., 2005). The type strains of species of the genus Deinococcus form a phylogenetically diverse group in a deeply branching lineage within the Bacteria (Asker et al., 2008). Deinococci have been isolated from diverse sources, notably from arid environments such as desert soils and rocks (Hirsch et al., 2004; de Groot et al., 2005; Rainey et al., 2005, 2007; Peng et al., 2009). At the time of writing, the genus contains 39 validly described species, nearly all of which have been

The GenBank accession numbers for the 16S rRNA gene sequences of strains $R 12^{\top}$ and $R 13^{\top}$ are EU025028 and FJ439568, respectively.

Fatty acid compositions of strains $\mathrm{R} 12^{\top}$ and $\mathrm{R} 13^{\top}$ and two-dimensional thin-layer chromatography of polar lipids of $D$. radiodurans $R 1^{\top}$, strain $R 12^{\top}$ and strain $R 13^{\top}$ are available with the online version of this paper. described in the past five years (http://www.bacterio.cict.fr/ d/deinococcus.html).

The present study was designed to establish the taxonomic status of two radiation-resistant, tetrad-forming strains, designated $\mathrm{R} 12^{\mathrm{T}}$ and $\mathrm{R} 13^{\mathrm{T}}$, which were isolated during a study on the bioremediation of radiation-contaminated soils in Xinjiang Province, China. The isolates were the subject of a polyphasic taxonomic study, which showed that they warranted recognition as novel species of the genus Deinococcus.

Strains $\mathrm{R} 12^{\mathrm{T}}$ and $\mathrm{R} 13^{\mathrm{T}}$ were isolated from a soil suspension after incubation at $30{ }^{\circ} \mathrm{C}$ for 14 days on a tryptoneglucose-yeast extract agar plate [TGY; $1 \%(\mathrm{w} / \mathrm{v})$ tryptone; $0.1 \%(\mathrm{w} / \mathrm{v})$ glucose; $0.5 \%(\mathrm{w} / \mathrm{v})$ yeast extract; $1.5 \%(\mathrm{w} / \mathrm{v})$ agar (Brim et al., 2003)]. The soil sample, which was collected from radiation-contaminated soil in the Xinjiang Uigur Autonomous Region of north-west China, had been exposed to a ${ }^{60} \mathrm{Co}$ source at a dose rate of $0.167 \mathrm{kGy} \mathrm{min}^{-1}$ at room temperature $\left(1 \mathrm{kGy}=10^{5} \mathrm{rads}\right)$ until it had received 
a dose of $15 \mathrm{kGy}$ gamma radiation. The isolates were maintained on TGY slants at $4{ }^{\circ} \mathrm{C}$ and as suspensions of cells in $20 \%(\mathrm{v} / \mathrm{v})$ glycerol at $-20{ }^{\circ} \mathrm{C}$. Biomass for the chemotaxonomic and molecular systematic studies was prepared in shake flasks of TGY broth at $30{ }^{\circ} \mathrm{C}$ for 2 days, harvested by centrifugation and washed twice in distilled water; cells for the chemical studies were freeze-dried.

Genomic DNA, extracted as described by Earl et al. (2002), was used as template for PCR-mediated amplification and sequencing following standard procedures (Rainey et al., 1997). The resultant almost complete sequences of isolates $\mathrm{R} 12^{\mathrm{T}}$ and $\mathrm{R} 13^{\mathrm{T}}$ (1459 and $1422 \mathrm{nt}$, respectively) were compared with $16 \mathrm{~S}$ rRNA gene sequences from GenBank by using the BLAST program (http://www.ncb.nlm.nih.gov/ BLAST) to determine their approximate phylogenetic position. The two gene sequences were then aligned with corresponding sequences of closely related species of the genus Deinococcus by using CLUSTAL w software (Thompson et al., 1994). Pairwise evolutionary distances were calculated using the Kimura two-parameter model (Kimura, 1980) and phylogenetic trees were generated by using the neighbour-joining (Saitou \& Nei, 1987) and maximum-parsimony (Goodman \& Pechère, 1977) tree-making algorithms from the MEGA 4.0 program (Kumar et al., 2004); this software was also used to generate bootstrap confidence values based on 1000 resamplings. The $\mathrm{G}+\mathrm{C}$ content of the genomic DNA of the strains was determined by using the thermal denaturation method (Marmur \& Doty, 1962) with Escherichia coli K-12 as control.

It can be seen from Fig. 1 that the two isolates and the type strain of Deinococcus radiodurans (DSM 20539 ${ }^{\mathrm{T}}$ ) formed a well delineated subclade in the $16 \mathrm{~S}$ rRNA gene tree, a taxon that was supported by all of the tree-making algorithms and by a $100 \%$ bootstrap value. Isolates $\mathrm{R} 12^{\mathrm{T}}$ and $\mathrm{R} 13^{\mathrm{T}}$ shared $16 \mathrm{~S}$ rRNA gene similarities with the $D$. radiodurans strains of 97 and $97.1 \%$, respectively, values which corresponded to 7 and $8 \mathrm{nt}$ differences. The isolates also shared a high 16S rRNA gene similarity (99\%), thereby necessitating DNA-DNA relatedness studies. The DNA $\mathrm{G}+\mathrm{C}$ contents of isolates $\mathrm{R} 12^{\mathrm{T}}$ and $\mathrm{R} 13^{\mathrm{T}}$ were 66.7 and $63.8 \%$, respectively.

The levels of DNA-DNA relatedness between the three members of the $D$. radiodurans $16 \mathrm{~S}$ rRNA gene subclade were determined by using the renaturation method (De Ley et al., 1970) and a Perkin Elmer Lambda 35UV/VIS spectrophotometer fitted with a PTP-1 peltier temperature controller. Genomic DNA preparations were sheared by ultrasonication to give a mean fragment size (300-700 bp) and the resultant samples adjusted to give an $\mathrm{OD}_{260}$ of 2.0 in $2 \times$ SSC buffer $(1 \times$ SSC is $0.15 \mathrm{M}$ sodium chloride and $0.015 \mathrm{M}$ sodium citrate). Denaturation was carried out at $99{ }^{\circ} \mathrm{C}$ for $10 \mathrm{~min}$ and hybridization at $76{ }^{\circ} \mathrm{C}$. Isolates $\mathrm{R} 12^{\mathrm{T}}$ and $\mathrm{R} 13^{\mathrm{T}}$ shared a DNA-DNA relatedness value of $58.5 \%$ and corresponding values of 29.5 and $33.3 \%$ with $D$. radiodurans DSM $20539^{\mathrm{T}}$, respectively. These results indicate that the three strains belong to distinct genomic species as the relatedness values are well below the $70 \%$ cut-off point recommended for the circumscription of bacterial species (Wayne et al., 1987).

Isolates $\mathrm{R} 12^{\mathrm{T}}$ and $\mathrm{R} 13^{\mathrm{T}}$ were examined for a range of diagnostic chemotaxonomic markers to determine whether or not they belonged to the genus Deinococcus. To this end, standard procedures were used to extract and detect the diamino acid in peptidoglycan preparations (Schleifer \& Kandler, 1972) and major polar lipids in whole cells (Tindall, 1990), including those of D. radiodurans DSM $20539^{\mathrm{T}}$. Similarly, menaquinones extracted after Minnikin et al. (1984) were separated by HPLC (Kroppenstedt, 1982). Cellular fatty acids were extracted, methylated, separated and identified by using the Sherlock Microbial Identification System (MIDI) (Sasser, 1990).

The isolates contained L-ornithine as the diamino acid of the peptidoglycan, and MK-8 as the predominant menaquinone. The major cellular fatty acids of isolates $\mathrm{R} 12^{\mathrm{T}}$ and $\mathrm{R} 13^{\mathrm{T}}$ were hexadecanoic acid $\left(\mathrm{C}_{16: 1} \omega 7 c: 46.4\right.$ and $54.3 \%$,

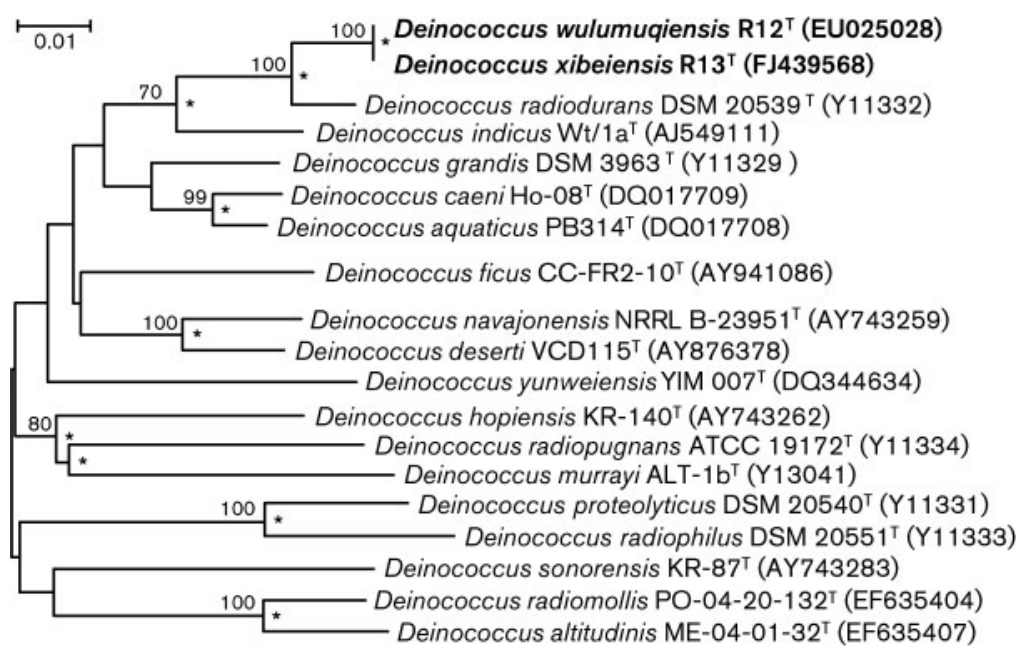

Fig. 1. Phylogenetic tree based on a distance matrix analysis of almost complete $16 \mathrm{~S}$ rRNA gene sequences showing relationships between isolates $\mathrm{R} 12^{\top}$ and $\mathrm{R} 13^{\top}$ and phylogenetically close members of the genus Deinococcus. Branches of the tree with asterisks were also found using the neighbour-joining and maximum-parsimony treemaking algorithms. Numbers at nodes indicate the levels of bootstrap support based on a neighbour-joining analysis of 1000 resampled datasets; only values $>70 \%$ are shown. Bar, $1 \%$ sequence divergence. 
respectively) and hexadecanoic acid $\left(\mathrm{C}_{16: 0}: 14.5\right.$ and $21.0 \%$, respectively). Small qualitative and quantitative differences were found in the fatty acid composition of the minor components of the two isolates, notably a higher proportion of $\mathrm{C}_{17: 1} \omega 8 \mathrm{c}$ in isolate $\mathrm{R} 12^{\mathrm{T}}$ compared with isolate $\mathrm{R} 13^{\mathrm{T}}$ (6.7 against $2.7 \%$ ), which is also predominant in D. radiodurans DSM $20539^{\mathrm{T}}$ (Rainey et al., 2005).

Based on their staining behaviour, the polar lipid patterns of $D$. radiodurans DSM $20539^{\mathrm{T}}$ and the two novel isolates consisted of various unknown glycolipids, phosphoglycolipids and polar lipids (Supplementary Figure S1, available in IJSEM Online). In all three strains, the patterns were dominated by unknown phosphoglycolipid PGL2. This is in line with previous results for species of the genus Deinococcus (Thompson et al., 1980; Embley et al., 1987; Ferreira et al., 1997; de Groot et al., 2005; Weon et al., 2007; Callegan et al., 2008; Im et al., 2008). The organisms also contained phosphoglycolipid PGL1, glycolipids GL2 and GL3, and an unknown polar lipid, a pattern typical of other species of the genus Deinococcus (Lai et al., 2006; Im et al., 2008; Kämpfer et al., 2008). However, the strains also showed differences in their polar lipid profiles which may be of diagnostic value. The two isolates lack a fifth glycolipid (GL5) compared with $D$. radiodurans DSM $20539^{\mathrm{T}}$. Isolate $\mathrm{R} 13^{\mathrm{T}}$ contained a first glycolipid and, like D. radiodurans DSM $20539^{\mathrm{T}}$, contained a characteristic aminophospholipid. All of the strains contained a spot composed of a red pigment.

The isolates were examined for phenotypic properties known to be of value in Deinococcus systematics. Gram staining was carried out by using a standard procedure, and cellular morphology and motility sought using light microscopy following growth on TGY agar for 3 days at $30{ }^{\circ} \mathrm{C}$. Catalase activity was determined by assessing bubble production following the addition of $3 \%(\mathrm{v} / \mathrm{v}) \mathrm{H}_{2} \mathrm{O}_{2}$ to colonies, and oxidase activity was determined by using $1 \%$ $(\mathrm{v} / \mathrm{v})$ tetramethyl-p-phenylenediamine. The ability of the strains to grow under different temperature and $\mathrm{pH}$ conditions and in the presence of $\mathrm{NaCl}$ was carried out using TGY medium. Single carbon source tests were carried out after Ferreira et al. (1997), and starch degradation was assessed using TGY agar as the basal medium; Lugol's iodine was added after plates had been incubated at $30{ }^{\circ} \mathrm{C}$ for 3 days. Susceptibility to erythromycin and rifampicin at $15 \mathrm{mg} \mathrm{ml}^{-1}$ was determined by using TGY agar plates that had been incubated at $30{ }^{\circ} \mathrm{C}$ for 3 days.

The novel isolates were Gram-stain-positive, non-motile, tetrad-forming cocci, which formed circular, shiny, reddish-orange colonies on TGY agar. Catalase and oxidase reactions were positive. Both strains grew at 10 to $55{ }^{\circ} \mathrm{C}$ and at $\mathrm{pH} 5.0$ to 12.0 , but differed in their optimal growth temperatures; isolate $\mathrm{R} 12^{\mathrm{T}}$ grew optimally at $37^{\circ} \mathrm{C}$ and isolate $\mathrm{R} 13^{\mathrm{T}}$ at $30{ }^{\circ} \mathrm{C}$. It can be seen from Table 1 that the isolates can be readily distinguished from one another and from the type strain of $D$. radiodurans by using a combination of phenotypic properties.
Table 1. Phenotypic properties separating isolates $R 12^{\top}$ and $\mathrm{R} 13^{T}$ from one another and from the type strain of $D$. radiodurans

Strains: 1, isolate $\mathrm{R} 12^{\mathrm{T}} ; 2$, isolate $\mathrm{R} 13^{\mathrm{T}} ; 3$, D. radiodurans DSM $20539^{\mathrm{T}}$. +, Positive; - , negative; ND, no data available; w, weakly positive result or growth. Data from this study.

\begin{tabular}{|lccc|}
\hline Characteristic & $\mathbf{1}$ & $\mathbf{2}$ & $\mathbf{3}$ \\
\hline Temperature range for growth $\left({ }^{\circ} \mathrm{C}\right)$ & $10-55$ & $10-55$ & $\mathrm{ND}$ \\
Optimum temperature $\left({ }^{\circ} \mathrm{C}\right)$ & 37 & 30 & 30 \\
pH range for growth & $5-12$ & $5-12$ & $\mathrm{ND}$ \\
Optimum pH & $7-8$ & 7 & $\mathrm{ND}$ \\
Growth on sole carbon sources & & & \\
Sucrose & - & + & - \\
Sorbitol & - & + & - \\
Arabinose & - & + & - \\
Maltose & $\mathrm{w}$ & + & $\mathrm{W}$ \\
Fucose & - & + & - \\
D-Mannose & - & + & + \\
Melezitose & + & + & - \\
D-Xylose & - & + & - \\
Rhamnose & - & + & - \\
Sodium citrate & - & + & - \\
Sodium oxalate & - & + & + \\
Starch degradation & + & + & - \\
Susceptibility to antibiotics $(15 \mu \mathrm{g}$ & & & \\
ml $\left.{ }^{-1}\right)$ & & & \\
Rifampicin & + & - & + \\
Erythromycin & - & - & + \\
& & & \\
\hline
\end{tabular}

Survival rates of the novel isolates in response to gamma and UV radiation were compared with those of $D$. radiodurans DSM $20539^{\mathrm{T}}$ and E. coli $\mathrm{DH} 5 \alpha$ via an established procedure (Ferreira et al., 1997). Strains were grown in modified TGY broth to exponential growth phase, at which point biomass was washed with sodium chloride $(0.85 \%, \mathrm{w} / \mathrm{v})$, centrifuged at $4{ }^{\circ} \mathrm{C}$ and resuspended in saline $(0.85 \%, \mathrm{w} / \mathrm{v})$ to give a concentration of $1 \times 10^{7}-10^{8}$ c.f.u. $\mathrm{ml}^{-1}$. Each suspension was divided into $2 \mathrm{ml}$ aliquots and exposed to a ${ }^{60} \mathrm{Co}$ source at a dose rate of $0.167 \mathrm{kGy} \mathrm{min}{ }^{-1}$ at room temperature; the gamma radiation doses were from zero to $20.0 \mathrm{kGy}$ in steps of 2.0 kGy. Treated samples were plated onto TGY agar plates and incubated at $30{ }^{\circ} \mathrm{C}$. Similarly, preparations were exposed to a $254 \mathrm{~nm}$ UV lamp for the desired dose and subsequently incubated at $30{ }^{\circ} \mathrm{C}$. The dose was monitored by using a VLX-30 radiometer. It can be seen from Fig. 2 that the isolates and positive control, unlike the negative control, showed little decrease in per cent survival when treated with gamma radiation at $3 \mathrm{kGy}$; the Deinococcus strains also showed resistance to $>10 \mathrm{kGy}$. In the case of UV radiation, the Deinococcus strains grew at the highest dosage of $746 \mathrm{~J} \mathrm{~m}^{-2}$; in contrast, the lethal dosage for the E. coli strain was $30 \mathrm{~J} \mathrm{~m}^{-2}$.

It is evident from the genotypic and phenotypic data that each of the isolates represents a novel species of the genus 


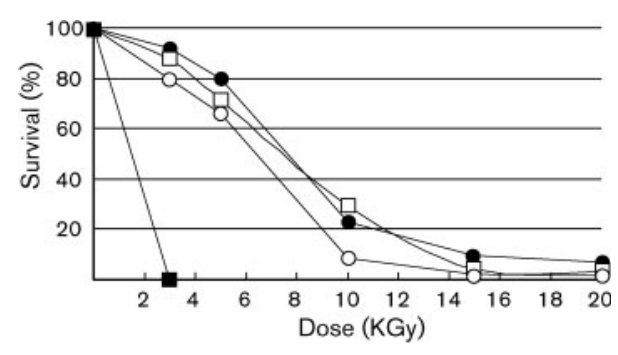

Fig. 2. Survival curves for isolates $R 12^{\top}, R 13^{\top}$, Deinococcus radiodurans DSM $20539^{\top}$ (DR) and Escherichia coli $\mathrm{DH} 5 \alpha$ following exposure to gamma radiation. $\bigcirc, \mathrm{R}_{13}{ }^{\mathrm{T}} ; \mathbf{O}, \mathrm{DR} ; \square$, $\mathrm{R} 12^{\mathrm{T}} ; \mathbf{\square}$, E. coli.

Deinococcus. It is proposed that isolates $\mathrm{R} 12^{\mathrm{T}}$ and $\mathrm{R} 13^{\mathrm{T}}$ be given the names Deinococcus wulumuqiensis sp. nov., and Deinococcus xibeiensis sp. nov., respectively.

\section{Description of Deinococcus wulumuqiensis sp. nov.}

Deinococcus wulumuqiensis sp. nov. (wu.lu.mu.qi.en'sis. N.L. masc. adj. wulumuqi referring to Urumchi, the Chinese phoneticization for Urumchi city, where the type strain was isolated).

Aerobic, Gram-stain-positive, non-spore-forming, nonmotile, tetrad-forming cocci. Reddish-orange, circular, opaque colonies (approx. 1.8-3.8 $\mathrm{mm}$ in diameter) are formed after incubation on TGY medium for 14 days at $37{ }^{\circ} \mathrm{C}$. The optimal growth $\mathrm{pH}$ and temperature are $\mathrm{pH}$ 7.0-8.0 and $37{ }^{\circ} \mathrm{C}$, respectively. L-Cystine, D-fructose, melezitose, L-leucine, L-proline, L-threonine, L-tryptophan, L-tyrosine and lactate can be utilized as sole carbon sources. Arabinose, galactose, fucose, dextrin, rhamnose, histidine, mannitose, sorbitol, cellobiose, D-xylose, raffinose, citrate, oxalate, succinate and benzoate cannot be utilized as sole carbon sources. Growth occurs in the presence of $1 \%(\mathrm{w} / \mathrm{v})$ $\mathrm{NaCl}$. The major cellular fatty acids are $\mathrm{C}_{16: 1} \omega 7 c, \mathrm{C}_{16: 0}$, $\mathrm{C}_{17: 1} \omega 8 c, \mathrm{C}_{16: 1} \omega 9 c, \mathrm{C}_{17: 1} \omega 6 c$ with small amounts of iso$\mathrm{C}_{16: 0}, \mathrm{C}_{15: 1} \omega 6 c, \mathrm{C}_{15: 0}, \mathrm{C}_{17: 0}$, iso- $\mathrm{C}_{16: 0} \mathrm{H}$, iso- $\mathrm{C}_{17: 1} \omega 9 c$, $\mathrm{C}_{15: 1} \omega 8 c, \mathrm{C}_{18: 1} \omega 7 c, \mathrm{C}_{14: 0}, \mathrm{C}_{16: 1} \omega 5 c, \mathrm{C}_{18: 1} \omega 9 c$ and $\mathrm{C}_{18: 0}$ (Supplementary Table $\mathrm{S} 1$ ). Gamma radiation resistant to $>10 \mathrm{kGy}$, UV resistant to $>700 \mathrm{~J} \mathrm{~m}^{-2}$. The $16 \mathrm{~S}$ rRNA gene similarity and DNA-DNA relatedness of the type strain with Deinococcus radiodurans DSM $20539^{\mathrm{T}}$ are 97 and $29.5 \%$, respectively. The DNA $\mathrm{G}+\mathrm{C}$ content of the type strain is $66.7 \mathrm{~mol} \%$.

The type strain, isolate $\mathrm{R} 12^{\mathrm{T}}$ (=CGMCC $1.8884^{\mathrm{T}}=\mathrm{NBRC}$ $105665^{\mathrm{T}}$ ), was recovered from radiation-contaminated soil collected in Xinjiang Province, China.

\section{Description of Deinococcus xibeiensis sp. nov.}

Deinococcus xibeiensis sp. nov. [xi.bei.en'sis. N.L. masc. adj. xibeiensis referring to Xibei, the Chinese phoneticization for north-west China, where the soil sample was collected (i.e. Xinjiang Province)].

Aerobic, Gram-stain-positive, non-spore-forming, nonmotile tetrad-forming cocci. Pinkish-red, circular, opaque colonies (approx. 3.2-4.5 $\mathrm{mm}$ in diameter) are formed after incubation on TGY medium for 14 days at $30{ }^{\circ} \mathrm{C}$. The optimal growth $\mathrm{pH}$ and temperature are $\mathrm{pH} 7.0$ and $30{ }^{\circ} \mathrm{C}$. Growth occurs in the presence of $1 \%(w / v) ~ N a C l$. Sucrose, sorbitol, maltose, galactose, fucose, mannitose, melezitose, xylose, arabinose, rhamnose, dextrin, mannitol, L-cystine, D-fructose, melezitose, L-leucine, L-proline, L-threonine, Ltryptophan, L-tyrosine, tartrate, oxalate and lactate can be utilized as sole carbon sources. Succinate, benzoate, histidine, raffinose and cellobiose cannot be utilized as sole carbon sources. The main cellular fatty acids are $\mathrm{C}_{16: 1} \omega 7 c, \mathrm{C}_{16: 0}, \mathrm{C}_{16: 1} \omega 9 c$ with small amounts of $\mathrm{C}_{17: 1} \omega 8 c$, $\mathrm{C}_{15: 0}, \mathrm{C}_{18: 1} \omega 7 c, \mathrm{C}_{17: 1} \omega 6 c, \mathrm{C}_{15: 1} \omega 6 c, \mathrm{C}_{17: 0}$, iso- $\mathrm{C}_{16: 0}$, iso$\mathrm{C}_{17: 1} \omega 9 c, \mathrm{C}_{14: 0}, \quad$ iso- $\mathrm{C}_{16: 0} \mathrm{H}, \mathrm{C}_{16: 1} \omega 5 c, \mathrm{C}_{15: 1} \omega 8 c$, $\mathrm{C}_{18: 1} \omega 9 c, \mathrm{C}_{14: 0} 2-\mathrm{OH}, \mathrm{C}_{18: 0}$ and $\mathrm{C}_{10: 0}$ (Supplementary Table S1). Gamma radiation resistant to $>10 \mathrm{kGy}$, UV resistant to $>700 \mathrm{~J} \mathrm{~m}^{-2}$. The $16 \mathrm{~S}$ rRNA gene similarity and DNA-DNA relatedness of the type strain with Deinococcus radiodurans DSM $20539^{\mathrm{T}}$ are 97.1 and $33.3 \%$, respectively. The DNA G + C content of the type strain is $63.8 \mathrm{~mol} \%$.

The type strain, isolate $\mathrm{R} 13^{\mathrm{T}}$ (=CGMCC $1.8885^{\mathrm{T}}=\mathrm{NRBC}$ $105666^{\mathrm{T}}$ ), was recovered from radiation-contaminated soil collected from Xinjiang Province, China.

\section{Acknowledgements}

This research work was supported by the Hi-Tech Research and Development Program of China (grant no. 2007AA021300) and by the Chinese Ministry of Agriculture (grant no. 200803034). The authors are grateful to Professor Min Wu (College of Life Sciences, Zhejiang University) for his help with the DNA-DNA relatedness studies, and to Professor Jean Euzéby (École Nationale Vétérinaire, Toulouse, France) for help with naming the organisms.

\section{References}

Asker, D., Awad, T. S., Beppu, T. \& Ueda, K. (2008). Deinococcus misasensis and Deinococcus roseus, novel members of the genus Deinococcus, isolated from a radioactive site in Japan. Syst Appl Microbiol 31, 43-49.

Brim, H., Venkateswaran, A., Kostandarithes, H. M., Fredrickson, J. K. \& Daly, M. J. (2003). Engineering Deinococcus geothermalis for bioremediation of high-temperature radioactive waste environments. Appl Environ Microbiol 69, 4575-4582.

Brooks, B. W. \& Murray, R. G. E. (1981). Nomenclature for 'Micrococcus radiodurans' and other radiation-resistant cocci: Deinococcaceae fam. nov. and Deinococcus gen. nov. including five species. Int J Syst Bacteriol 31, 353-360.

Callegan, R. P., Nobre, M. F., McTernan, P. M., Battista, J. R., NavarroGonzález, R., McKay, C. P., da Costa, M. S. \& Rainey, F. A. (2008). Description of four novel psychrophilic, ionizing radiation-sensitive Deinococcus species from alpine environments. Int J Syst Evol Microbiol 58, 1252-1258.

de Groot, A., Chapon, V., Servant, P., Christen, R., Fischer-Le Saux, M., Sommer, S. \& Heulin, T. (2005). Deinococcus deserti sp. nov. a 
gamma-radiation-tolerant bacterium isolated from the Sahara Desert. Int J Syst Evol Microbiol 55, 2441-2446.

De Ley, J., Cattoir, H. \& Reynaerts, A. (1970). The quantitative measurements of DNA hybridization from renaturation rates. Eur $J$ Biochem 12, 133-142.

Earl, A. M., Mohundro, M. M., Mian, I. S. \& Battista, J. R. (2002). The IrrE protein of Deinococcus radiodurans $\mathrm{R} 1$ is a novel regulator of recA expression. J Bacteriol 184, 6216-6224.

Embley, T. M., O'Donnell, A. G., Watt, R. \& Rostron, J. (1987). Lipid and cell wall amino acid composition in the classification of members of the genus Deinococcus. Syst Appl Microbiol 10, 20-27.

Ferreira, A. C., Nobre, M. F., Rainey, F. A., Silva, M. T., Wait, R., Burghardt, J., Chung, A. P. \& Da Costa, M. S. (1997). Deinococcus geothermalis sp. nov. and Deinococcus murrayi sp. nov., two extremely radiation-resistant and slightly thermophilic species from hot springs. Int J Syst Bacteriol 47, 939-947.

Goodman, M. \& Pechère, J. F. (1977). The evolution of muscular parvalbumins investigated by the maximum parsimony method. J Mol Evol 9, 131-158.

Hirsch, P., Gallikowski, C. A., Siebert, J., Peissl, K., Kroppenstedt, R. M., Schumann, P., Stackebrandt, E. \& Anderson, R. (2004). Deinococcus frigens sp. nov., Deinococcus saxicola sp. nov., and Deinococcus marmoris sp. nov., low temperature and draught-tolerating, UVresistant bacteria from continental Antarctica. Syst Appl Microbiol 27, 636-645.

Im, W.-T., Jung, H.-M., Ten, L. N., Kim, M. K., Bora, N., Goodfellow, M., Lim, S., Jung, J. \& Lee, S.-T. (2008). Deinococcus aquaticus sp. nov., isolated from fresh water, and Deinococcus caeni sp. nov., isolated from activated sludge. Int J Syst Evol Microbiol 58, 2348-2353.

Kämpfer, P., Lodders, N., Huber, B., Falsen, E. \& Büsse, H.-J. (2008). Deinococcus aquatilis sp. nov., isolated from water. Int J Syst Evol Microbiol 58, 2803-2806.

Kimura, M. (1980). A simple method for estimating evolutionary rates of base substitutions through comparative studies of nucleotide sequences. J Mol Evol 16, 111-120.

Kroppenstedt, R. M. (1982). Separation of bacterial menaquinones by HPLC using reverse phase (RP18) and a silver loaded ion exchanger as stationary phases. J Liq Chromatogr 5, 2359-2367.

Kumar, S., Tamura, K. \& Nei, M. (2004). MEGA 3: integrated software for molecular evolutionary genetics analysis and sequence alignment. Brief Bioinform 5, 150-163.

Lai, W.-A., Kämpfer, P., Arun, A. B., Shen, F.-T., Huber, B., Rekha, P. D. \& Young, C.-C. (2006). Deinococcus ficus sp. nov., isolated from the rhizosphere of Ficus religiosa L. Int J Syst Evol Microbiol 56, 787-791.

Marmur, J. \& Doty, P. (1962). Determination of base composition of deoxyribonucleic acid from its denaturation temperature. J Mol Biol 5, 109-118.
Mattimore, V. \& Battista, J. R. (1996). Radioresistance of Deinococcus radiodurans: functions necessary to survive ionizing radiation are also necessary to survive prolonged desiccation. J Bacteriol 178, 633-637.

Minnikin, D. E., O’Donnell, A. G., Goodfellow, M., Alderson, G., Athalye, M., Schaal, A. \& Parlett, J. H. (1984). An integrated procedure for the extraction of bacterial isoprenoid quinones and polar lipids. J Microbiol Methods 2, 233-241.

Peng, F., Zhang, L., Luo, X., Dai, J., An, H., Tang, Y. \& Fang, C. (2009). Deinococcus xinjiangensis sp. nov., isolated from desert soil. Int J Syst Evol Microbiol 59, 709-713.

Rainey, F. A., Nobre, M. F., Schumann, P., Stackebrandt, E. \& da Costa, M. S. (1997). Phylogenetic diversity of the deinococci as determined by $16 \mathrm{~S}$ ribosomal DNA sequence comparison. Int J Syst Bacteriol 47, 510-514.

Rainey, F. A., Ray, K., Ferreira, M., Gatz, B. Z., Nobre, M. F., Bagaley, D., Rash, B. A., Park, M.-J., Earl, A. M. \& other authors (2005). Extensive diversity of ionizing-radiation-resistant bacteria recovered from a Sonoran Desert soil and the description of nine new species of the genus Deinococcus obtained from a single soil sample. Appl Environ Microbiol 71, 5225-5235.

Rainey, F. A., Ferreira, M., Nobre, M. F., Ray, K., Bagaley, D., Earl, A. M., Battista, J. R., Gómez-Silva, B., McKay, C. P. \& da Costa, M. S. (2007). Deinococcus peraridilitoris sp. nov., isolated from a coastal desert. Int $J$ Syst Evol Microbiol 57, 1408-1412.

Saitou, N. \& Nei, M. (1987). The neighbor-joining method: a new method for reconstructing phylogenetic trees. Mol Biol Evol 4, 406425.

Sasser, M. (1990). Identification of bacteria by gas chromatography of cellular fatty acids, MIDI Technical Note 101. Newark, DE: MIDI Inc.

Schleifer, K. H. \& Kandler, O. (1972). Peptidoglycan types of bacterial cell walls and their taxonomic implications. Bacteriol Rev 36, 407-477.

Thompson, B. G., Anderson, R. \& Murray, R. G. (1980). Unusual polar lipids of Micrococcus radiodurans strain Sark. Can J Microbiol 26, 1408-1411.

Thompson, J. D., Higgins, D. G. \& Gibson, T. J. (1994). CLUSTAL W: improving the sensitivity of progressive multiple sequence alignment through sequence weighting, position-specific gap penalties and weight matrix choice. Nucleic Acids Res 22, 4673-4680.

Tindall, B. J. (1990). Lipid composition of Halobacterium lacusprofundi. FEMS Microbiol Lett 66, 199-202.

Wayne, L. G., Brenner, D. J., Colwell, R. R., Grimont, P. A. D., Kandler, O., Krichevsky, M. I., Moore, L. H., Moore, W. E. C., Murray, R. G. E. \& other authors (1987). International Committee on Systematic Bacteriology. Report of the ad hoc committee on reconciliation of approaches to bacterial systematics. Int J Syst Bacteriol 37, 463-464.

Weon, H.-Y., Kim, B.-Y., Schumann, P., Son, J.-A., Jang, J., Go, S.-J. \& Kwon, S.-W. (2007). Deinococcus cellulosilyticus sp. nov., isolated from air. Int J Syst Evol Microbiol 57, 1685-1688. 